\title{
How Do Institutional Investors Interact With Sell-Side Analysts?
}

\author{
Grace Il Joo Kang, Singapore University of Social Sciences, Singapore \\ Yong Keun Yoo, Korea University Business School, South Korea \\ Seung Min Cha, Kyonggi University, South Korea
}

\begin{abstract}
This paper examines how institutional investors interact with sell-side analysts (hereafter, SSAs) in Korean stock market. In particular, we examine the role of institutional investors as a more sophisticated mechanism which incorporates sell-side analysts' stock recommendation, target price, and earnings forecast more rapidly than individual investors do. Moreover, we examine whether institutional investors differentiate the quality of sell-side analysts' information. By using a sample of 1,421 firm-year observations in Korean stock market during 2001-2011, we find that the change of institutional investor's ownership has a significantly positive association with the level of equity value estimates based on SSAs' earnings forecasts relative to stock prices and their stock recommendation which are considered as SSAs' indicator of stock market's mispricing. In addition, we find that only when SSAs provide more accurate earnings forecasts, institutional investors incorporate SSA's information into their stock trading. Thus, we conclude that institutional investors in Korean stock market contribute to the enhancement of stock market efficiency by incorporating SSAs' information into their stock trading more rapidly than individual investors. Our findings add to the literature by shedding a light on the unobserved interaction among more sophisticated stock market participants, such as institutional investors and sell-side analysts.
\end{abstract}

Keywords: Sell-Side Analyst; Institutional Ownership; Analysts' Earnings Forecasts; Target Prices; Stock Recommendations

\section{INTRODUCTION}

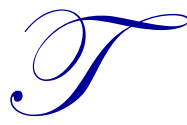

his study examines how institutional investors interact with sell-side analysts (hereafter, SSAs) in Korean stock market. Lee (2001) suggests that stock prices converge toward the intrinsic value of equity over time, and that convergence is achieved only at substantial social costs. Therefore, a temporary divergence between stock price and intrinsic value of equity is inevitable. Thus, given that efficient stock markets is a necessary condition for the economically efficient allocation of social resources among firms, it is important to identify which factors either facilitate or impede stock price convergence toward intrinsic value of equity.

Prior studies suggest that SSAs' information, such as earnings forecasts, target prices, and stock recommendations, can predict future stock returns (e.g., Frankel \& Lee, 1998; Lee, Myers, \& Swaminathan, 1999; Cha \& Yoo, 2010). Their results imply that SSAs provide value relevant information that can facilitate stock price convergence toward intrinsic value of equity. However, SSAs, as information intermediary, cannot accelerate stock price convergence toward intrinsic value of equity by themselves. Thus, there must be some stock market participants who actually trade stocks incorporating SSAs' information. Given that SSAs' information has the potential to enhance stock market efficiency, it is important to examine which market participants incorporate it more actively than the others. Prior studies suggest that institutional investors outperform individual investors and that their stock trading leads to subsequent stock returns (e.g., Nofsinger \& Sias, 1999; Gompers \& Metrick, 2001). Therefore, we focus on the role of institutional investors as the stock market participants who more actively incorporate SSAs' information.

In prior literature, the roles of sell-side analysts and institutional investors on the enhancement of stock market efficiency are separately examined. However, the interaction between SSAs and institutional investors is not fully investigated. Although Chen \& Cheng (2006) and Busse, Green, and Jegadeesh (2012) find that a change in institutional ownership is positively correlated with SSAs' stock recommendations, they do not examine whether 
institutional investors incorporate more comprehensive set of SSAs' information, such as earnings forecasts, target prices as well as stock recommendations. Furthermore, there is a paucity of evidence on whether institutional investors consider the quality of SSA's information when incorporating it into their stock trading. This study attempts to fill such a void in the literature.

More specifically, we examine the association between the change of institutional ownership and SSAs' indicator of stock market's mispricing, such as equity value estimate based on their earnings forecasts relative to stock price (hereafter, V/P ratio), target price relative to stock price, and stock recommendation. If institutional investors incorporate SSAs' indicators of stock mispricing more rapidly than individual investors, there will be positive associations between institutional ownership and SSAs' mispricing indicators. If it is the case, we can suggest that institutional investors take more active role in incorporating SSAs' value relevant information into stock price and that they act as a more sophisticated mechanism to enhance stock market efficiency. In addition, to support the causal relationship between SSAs' information and institutional ownership, we examine whether institutional investors' trading behavior affects SSAs' information as an alternative hypothesis for the association between institutional ownership and SSAs' mispricing indicators.

On the other hand, we examine whether institutional investors selectively incorporate more accurate SSAs' information into their stock trading. Prior literature indicates that SSAs' information is not free from bias and noise although SSAs' information is useful for the prediction of future stock returns. For example, Irvine (2004) suggests that SSAs provide optimistically biased information. Malmendier and Shanthikumar (2014) and Kim and Eum (2006) suggest that SSAs who work for brokerage houses update earnings forecasts timely but slowly, and that they downgrade their stock recommendations slowly to "Hold" or "Sell" and upgrade them promptly to "Buy". Furthermore, Bradshaw (2004) suggest that SSAs' stock recommendation is not consistent with the V/P ratio, which is considered as a mispricing indicator based on SSAs' earnings forecasts. Thus, it is important to investigate whether institutional investors, as a more sophisticated mechanism to enhance stock market efficiency by actively incorporating SSAs' information, can distinguish the quality of SSAs' information. Loh and Mian (2006) suggest that as SSAs' earnings forecasts are more accurate, the returns from stock trading based SSAs' stock recommendation are higher. A survey by Cheng, Liu, and Qian (2006) indicates that buy-side analysts are more dependent on SSAs' earnings forecasts when they are more accurate. Thus, in this paper, we examine whether institutional investors incorporate more actively SSAs' information as SSAs' earnings forecasts are more accurate.

Using a sample of 1,421 firm-year observations in Korean stock market during 2001 and 2011, we find that the change of institutional investor's ownership has a significantly positive association with the level of equity value estimates based on SSAs' earnings forecasts relative to stock prices (V/P ratio) as well as SSAs' stock recommendations. This result indicates that institutional investors increase their equity ownership for the firms to which SSAs issue more favorable information. That is, institutional investors incorporate SSAs' indicators of stock market's mispricing into their stock trading more rapidly than individual investors do, which in turn suggests that institutional investors take a more active role in incorporating SSA's information into stock prices. To the contrary, we find that SSAs' information is not affected by institutional investors' trading behavior. Therefore, we can conclude that our main results support the causality relationship in which institutional investors trade stocks incorporating SSAs' information, but not vice versa. Lastly, we find that the change of institutional investor's ownership has a significantly positive association with SSAs' information only when SSAs provide relatively more accurate earnings forecasts. This result indicates that institutional investors can distinguish the quality of SSAs' information, which also supports that institutional investors act as a more sophisticated mechanism to enhance stock market efficiency.

This study makes important contributions to the literature as follows. First, this study provides a piece of important evidence that institutional investors act as a more sophisticated mechanism in incorporating SSAs' value relevant information more rapidly than individual investors do. This evidence adds to the prior literature which examines institutional investors' sophistication in stock market. Second, this study indicates that institutional investors can differentiate the quality of SSAs' information. Overall, this study contributes to the enhancement of our knowledge about the unobserved interaction among more sophisticated stock market participants, such as sell-side analysts and institutional investors. 
The remainder of paper is organized as follows. Section 2 briefly reviews prior studies and develops hypotheses. Section 3 describes our research method and sample selection. Section 4 reports the empirical findings and Section 5 concludes.

\section{LITERATURE REVIEW AND HYPOTHESES DEVELOPMENT}

\subsection{Literature Review}

This study examines the interaction between institutional investors, who are the most sophisticated stock traders, and sell-side analysts, who are the most prominent information intermediaries in the stock market. The role of institutional investors and/or SSAs on stock market efficiency is established by prior studies.

A stream of research examines whether sell-side analysts can contribute to the enhancement of stock market efficiency. First, prior literature investigates whether SSAs' earnings forecasts can provide value relevant information to stock markets. For example, Brown, Griffin, Hagerman, and Zmijewski (1987) suggest that SSAs' earnings forecasts are superior to the univariate time-series models of previous earnings on the accuracy of future earnings prediction. Stickel (1991) suggest that analysts' earnings forecast revision improves the return from stock trading strategy, and Gleason and Lee (2003) find that additional analyst coverage facilitates faster stock price adjustment to analysts' forecast revision. While Elgers, Lo, and Pfeiffer (2001) suggest that the ratio of stock price to analysts' earnings forecast predicts future stock returns, Lee et al. (1999) suggest that equity value estimates based on analysts' earnings forecast rather than historical earnings are better predictors of future stock prices. Frankel and Lee (1998) also indicate that equity value estimates, based on SSAs' earnings forecasts, relative to stock prices (V/P ratio) can predict future stock returns. Furthermore, Ali, Hwang, and Trombley (2003) suggest that the effect of "V/P ratio" reported by Frankel and Lee (1998) is derived by stock market's mispricing rather than by omitted risk factors. Cha and Yoo (2010) also find that SSAs' earnings forecasts can predict future stock returns in Korean stock market.

Second, numerous studies examine the future stock return predictability of SSAs' stock recommendation. Womack (1996) finds that SSAs' upgrades and downgrades of their stock recommendation can predict future stock returns. Jegadeesh and Kim (2006) also find that SSAs' upgraded stock recommendations are associated with positive future stock returns. Barber et al. (2001) conclude that the strategy to buy stocks with "strong buy" recommendation leads to positive abnormal stock returns.

Third, prior literature examines whether SSAs' target price also contains value relevant information to predict future stock return. Brav and Lehavy (2003) find that stock market reacts to SSAs' revision of their target prices. Asquith, Mikhail, and $\mathrm{Au}$ (2005) find that SSAs' target price revisions can explain variations of stock prices. Bianchini, Bonini, Salvi, and Zanitti (2008) and Bradshaw, Brown, and Huang (2013) conclude that SSAs' target price and its change are positively associated with future stock return. Kim and Eum (2006) also find that information provided by SSAs, such as stock recommendation and target price revision, significantly affects stock prices in Korean stock market.

On the other hand, prior studies suggest that institutional investors are more sophisticated investors in the stock market and so their trading strategy predicts future stock returns. Institutional investors are better at analyzing and understanding information than individual investors, because institutional investors can access company information more easily and monitor management at a lower cost than individual investors (Kang \& Stulz 1997; Barber \& Odean 2008). Jiambalvo, Rajgopal, and Venkatachalam (2002) find that the extent to which stock prices lead earnings is positively associated with institutional ownership. Gompers and Metrick (2001) find that institutional investors almost doubled their stock shares from 1980 to 1996, and that the level of institutional ownership can help estimate future stock returns due to the compositional shift in ownership towards institutional investors. In addition, Yan and Zhang (2009) suggest that the association between institutional predictive ability and abnormal stock return, suggested by Gompers and Metrick (2001), is derived from short-term institutional investors. Sias, Starks, and Titman (2001) find that institutional investors lead the stock returns and perform better than individual ones, while Odean (1999) suggests that individual investors' portfolios do not outperform the market benchmark. Nofsinger and Sias (1999) also find that positive association between annual change in institutional ownership and stock returns over herding interval is contrary to change in individual ownership. Furthermore, Grinblatt and Keloharju (2000) suggest that institutional investors choose more attractive stocks, whereas individual investors are eager to cash out on winning stocks, in 
Finland's stock market. Bae and Park (2007) find a significantly positive association between institutional ownership and subsequent stock returns in Korean stock market, and Kim and Cheon (2004) also find that foreign and domestic institutional investors acquire positive stock returns with superior information advantage.

To the extent that institutional investors perform better than individual investors do in stock market, it is important to investigate which factor in stock market cause a superior sophistication of institutional investors. While prior studies suggest that the superior sophistication of institutional investor is determined by herding or momentum trading strategy (e.g., Wermers, 1999; Chen, Jegadeesh, \& Wermers, 2000), there is limited research on whether a closer interaction between institutional investors and SSAs can lead to the superior sophistication of institutional investors.

\subsection{Hypothesis Development}

As described in previous section, prior literature suggests that sell-side analysts' summary information, such as earnings forecasts, stock recommendations and target prices, provide stock investors with useful information to predict future stock returns. That is, SSAs' forecasting information has a potential to enhance the efficiency of stock market. However, SSAs cannot accelerate the convergence of stock price toward its intrinsic value by themselves, because SSAs just provide stock market participants with information to guide their actual trading. Thus, to make it possible that SSAs' information actually facilitate the convergence of stock price into its intrinsic value, some investors, who actually trade stocks incorporating SSAs' information, should play a role. That is, investors' execution of SSAs' trading guidance is essential for SSAs' information to enhance the stock market efficiency. In this study, we focus on the role of institutional investors as more sophisticated stock market participants who incorporate more actively SSAs' value relevant information.

One of the distinct channels of the interaction between SSAs and institutional investors can be described as follows. SSAs receive, process information from diverse sources, communicating it first with institutional investors in concise forms, such as earnings forecasts, stock recommendations and target prices. Then, subsequently, institutional investors incorporate such information into their stock trading more rapidly. ${ }^{1}$ Anecdotal evidence also shows that the main resources of institutional investors' equity research are provided by brokerage and investment banking firms with SSAs in exchange for a trading commission (Irvine, 2004; Cheng et al. 2006). In practice, institutional investors and SSAs have regular lunch meetings or conference calls. Furthermore, SSAs participate in investor relation meetings and meet firm's management together with institutional investors. Thus, those institutional investors may spend more time to analyze the company itself and/or related industry in-depth, which is covered by SSAs (Cheng et al. 2006).

Therefore, we expect that institutional investors are likely to incorporate SSAs' information more rapidly than individual investors do. If institutional investors incorporate SSAs' indicators of mispricing more rapidly than individual investors, there will be positive associations between institutional ownership and analysts' indicators of stock market's mispricing, such as V/P ratio, target price, and stock recommendations. Thus, our first hypothesis is as follows.

H1: There is a positive association between the change of institutional investors' ownership and sell-side analysts' indicators of stock market's mispricing ( $\mathrm{V} / \mathrm{P}$ ratios, target prices, stock recommendations).

Sell-side analysts have conflicts of interest and so provide optimistically biased earnings forecasts (Irvine, 2004). Malmendier and Shanthikumar (2014) and Kim and Eum (2006) suggest that SSAs' revision of stock recommendation is also optimistically biased. Furthermore, Bradshaw (2004) suggest that SSAs provide inconsistent information between earnings forecasts and stock recommendations. Thus, as a necessary condition that institutional investors can enhance stock market efficiency by incorporating SSAs' information into their stock trading, they should be able to selectively incorporate more accurate SSAs' information into their stock trading. Therefore, our second hypothesis investigates whether institutional investors are likely to incorporate SSAs' information more actively into their stock trading as SSAs provide more accurate forecast information. Given that institutional investors perform better than

${ }^{1}$ While it can be alternatively argued that institutional investors may depends on information from buy-side analysts, Groysberg, Healy, and Serafeim (2013) suggest that buy-side analysts cover more stocks than SSAs, and that buy-side analysts report less accurate, less informative, and more biased information than SSAs do. 
individual investors do in stock market, we expect that institutional investors can distinguish the quality of SSAs' information. Loh and Mian (2006) suggest that as SSAs' earnings forecasts are more accurate, the returns from stock trading based SSAs' stock recommendation are higher. Thus, we expect that institutional investors incorporate more actively SSAs' information than individual investors as SSAs' earnings forecasts are more accurate. Thus, our second hypothesis is as follows.

H2: There is a stronger positive association between the change of institutional investors' ownership and sell-side analysts' indicators of stock market's mispricing (V/P ratios, target prices, stock recommendations) as analysts' earnings forecasts are more accurate.

\section{RESEARCH METHOD AND SAMPLE SELECTION}

\subsection{Measurement of Sell-Side Analysts' Indicators of Stock Market's Mispricing}

In this study, we consider SSAs' earnings forecasts, target prices and stock recommendations as the summary information which institutional investors incorporate into their stock trading. More specifically, we examine the association between the change of institutional ownership and SSAs' indicators of stock market's mispricing based on such information. The measurement of SSAs' indicators of stock market's mispricing from target price and stock recommendation is very straightforward. We use the ratio of target price to stock price, and the score from stock recommendations (i.e., higher score indicates stronger recommendation to buy stocks) as the SSAs' mispricing indicators. However, SSAs' indicators of mispricing from earnings forecasts are not explicitly observable. Prior research suggests that equity value estimates based on SSAs' earnings forecast relative to stock price (V/P ratio) can predict future stock return (Frankel \& Lee, 1998; Ali et al. 2003; Cha \& Yoo, 2010). Because SSAs' earnings forecasts are the most important input into the measurement of $\mathrm{V} / \mathrm{P}$ ratio, their results imply that $\mathrm{V} / \mathrm{P}$ ratio can be considered as the SSAs' indicators of stock market's mispricing based on their earnings forecasts. Thus, we use V/P ratio as the proxy of such an indicator from SSAs' earnings forecasts. For all of SSAs' indicators of stock market's mispricing, a higher (lower) value of each indicator implies investors' underpricing (overpricing) of stocks.

To convert SSAs' earnings forecasts into equity value estimate, which is necessary to measure V/P ratio, we consider two representative implementations of residual income valuation model (e.g., Liu, Nissim, and Thomas, 2002). ${ }^{2}$ Accounting researchers use the residual income valuation (RIV) model because it links equity value to the firm's accounting information with the clean surplus relation (Ohlson, 1995). The RIV model approach is that the equity value of the firm is the sum of current book value of equity and the present value of the future residual incomes. To estimate future residual income, we use one-, and two-year ahead SSAs' earnings forecasts as the inputs. Then, we apply the representative assumptions in prior literature to estimate the residual income beyond two years ahead. The first RIV model ( $\mathrm{V}_{\mathrm{RIVC}}$ ) assumes that the residual earnings remain constant after two years ahead (Frankel \& Lee, 1998; Lee et al. 1999; Liu et al. 2002; Ali et al. 2003; Jorgensen et al. 2011). We compute future book values by using clean surplus relation in which the book value of equity in the future year equals the beginning of book value of equity and the estimated earnings, less the estimated dividends. We compute the cost of equity capital based on Capital Asset Pricing Model (CAPM):

$$
V_{R I V C}=b v_{t}+\sum_{s=1}^{2}\left(\frac{E_{t}\left(e p s_{t+s}-r_{t} \times b v_{t+s-1}\right)}{\left(1+r_{t}\right)^{s}}\right)+\frac{E_{t}\left(e p s_{t+2}-r_{t} \times b v_{t+1}\right)}{r_{t} \times\left(1+r_{t}\right)^{2}}
$$

where $b v_{t}$ is the book value per share at year $\mathrm{t}$; epst are the earnings per share during year $\mathrm{t}$; and $r_{t}$ is the cost of equity capital during year $\mathrm{t}$.

The second RIV model (VRIVI) assumes that firm's profitability, measured by return on equity (ROE), trends linearly from the level computed from SSAs' two-year-ahead earnings forecasts into the industry median of return on equity by the 12th year, and after 12th year the residual income is constant. Following Liu et al. (2002), we winsorize the

\footnotetext{
${ }^{2}$ We consider equity value estimates derived from the residual income valuation model ( $V_{R I V C}$ and $\left.V_{R I V I}\right)$ because Jorgensen et al. (2011) suggest that the accuracy of equity value estimates from the alternative earnings based valuation model, i.e., abnormal earnings growth model is lower. In a sensitivity test, we also use V/P ratios based on abnormal earnings growth model (Gode \& Mohanram, 2003; Easton, 2004), and the untabulated result is qualitatively similar.
} 
median of return on equity in the industry at the risk free rate and $20 \%$ :

$$
V_{R I V I}=b v_{t}+\sum_{s=1}^{2}\left(\frac{E_{t}\left(e p s_{t+s}-r_{t} \times b v_{t+s-1}\right)}{\left(1+r_{t}\right)^{s}}\right)+\sum_{s=3}^{11} \frac{\left[E_{t}\left(R O E_{t+s}-r_{t}\right)\right] \times b v_{t+s-1}}{\left(1+r_{t}\right)^{s}}+\frac{\left[E_{t}\left(R O E_{t+12}-r_{t}\right)\right] \times b v_{t+11}}{r_{t} \times\left(1+r_{t}\right)^{11}}
$$

where $R O E_{t}$ is the return on equity during year $\mathrm{t}$.

Then, we calculate the ratio of equity value estimate from each implementation to stock price $\left(V_{R I V C} / P, V_{R I V I} / P\right)$. In addition, to reduce potential measurement errors, we calculate the third $\mathrm{V} / \mathrm{P}$ ration by taking the average of $V_{R I V C} / P$ and $V_{R I V I} / P\left(V_{A V E R} / P\right)$.

\subsection{Regression Equation}

To examine our hypotheses, we use the change of institutional ownership as the dependent variable, and SSAs' indicators of stock market's mispricing (V/P ratio, target price, and stock recommendation) as independent variables. More specifically, our main regression equation is as follows.

$$
\begin{aligned}
\Delta I N S T I T= & \beta_{0}+\beta_{1} V_{\text {RIVC }} / P\left(V_{R I V I} / P, V_{A V E R} / P\right)+\beta_{2} \text { TARGET }+\beta_{3} \text { RECOM }+ \\
& \beta_{4} \text { InSIZE }+\beta_{5} \text { YIELD }+\beta_{6} \text { BETA }+\beta_{7} \text { InB } / M+\beta_{8} L E V E R A G E+ \\
& \beta_{9} \text { VOLUME }+\beta_{10} \text { lagRET } 12+\text { Year Dummies }+ \text { Industry Dummies }+\varepsilon
\end{aligned}
$$

where $\triangle I N S T I T$ is a change in institutional ownership for a year after the SSAs' information is disclosed at the beginning of year; $V_{R I V C} / P$ are the equity value estimates, which is inferred from $R I V C$ model, scaled by stock price at the beginning of the year; $V_{R I V I} / P$ are the equity value estimates, which is inferred from RIVI model, scaled by stock price at the beginning of the year; $V_{A V E R} / P$ is the average of $V_{R I V C} / P$ and $V_{R I V I} / P$; TARGET is the SSAs' target price divided by the stock price at the beginning of year; RECOM is the SSAs' stock recommendation at the beginning of year $(1=$ Strong Sell, $2=$ Sell, $3=$ Hold, $4=$ Buy, and $5=$ Strong Buy $)$ InSIZE is the natural $\log$ of the market value of equity; YIELD is the dividend per share divided by stock price at the beginning of year; BETA is the systematic risk estimated by regressing 30 prior monthly stock return and up to 60 prior monthly returns against the corresponding market index; $\ln B / M$ is the natural $\log$ of ratio of book value of equity to market value of equity; $L E V E R A G E$ is total liability divided by total assets; VOLUME is the average of the ratio of daily trading volume divided by the number of shares outstanding; lagRET12 is the stock return of each firm during the previous year; Year Dummies are year indicators; Industry Dummies are industry indicators based on the two-digit industry code.

We use the change in institutional ownership (DINSTIT) for a year after the SSAs' information is disclosed at the beginning of year as dependent variable. As independent variables, we use $V_{R I V C} / P, V_{R I V I} / P$, and $V_{A V E R} / P$. We also include SSAs' target prices divided by stock prices (TARGET) and stock recommendations (RECOM) at the beginning of the year as additional independent variables. We use stock recommendations from the majority of Korean brokerage houses and classify them into five categories: "Strong Buy," "Buy," "Hold," "Sell," and "Strong Sell," with values ranging from 1 to $5(1=$ Strong Sell, $2=$ Sell, $3=$ Hold, $4=$ Buy, and $5=$ Strong Buy $)$, respectively. Because a higher (lower) value of SSAs' mispricing indicator implies investors' underpricing (overpricing) of stocks, if institutional investors incorporate SSAs' mispricing indicators more rapidly than individual investors, there will be a positive association between the change of institutional ownerships and SSAs' mispricing indicators.

To analyze the association between the change in institutional ownership and SSAs' indicators of stock market's mispricing, we should control for the other factors that might affect the change of institutional ownership. Prior research finds various stock characteristics, which affect institutional investors' stock trading (e.g., Gompers \& Metrick, 2001; Chen \& Cheng, 2006). Institutional investors prefer the stocks with lower volatility of stock price and higher dividend yields, because they are restricted to the prudence of fiduciary regulation, while they prefer more liquid and larger stocks because of richer information environment and lower transaction cost (Gompers \& Metrick, 2001). Thus, we include market beta (BETA), dividend yield (YIELD), firm size (InSIZE), and turnover (VOLUME) as control variables. Jegadeesh et al. (2004) suggest that institutional investors are more likely to invest in glamour than value stocks, because it is short to earn intended positive stock returns by investing in value stocks. Thus, we add book to market ratio $(\ln B / M)$ as control variable. Prior studies also find that institutional investors buy stocks with 
positive momentum (Grinblatt, Titman, \& Wermers, 1995; Jegadeesh, Kim, Krische, \& Lee, 2004), and so we include previous year's stock return (lagRET12). We also add leverage (LEVERAGE) as control variable because institutional investors' ownership is negatively related to the level of leverage (Bathala, Moon, \& Rao, 1994). Lastly, our regression model includes year and industry dummy variables to control for the variability of the change in institutional ownership across year and industry.

On the other hand, to support the causal relationship between SSAs' information and institutional ownership, we examine whether institutional investors' trading behavior affects SSAs' information as an alternative hypothesis for the association between the change of institutional ownership and SSAs' mispricing indicators. To address this empirical issue, we regress the changes in SSAs' mispricing indicators on the change in institutional investor's ownership for the previous year. Following Ali et al. (2003), we control for the well-known risk proxies since the change of $\mathrm{V} / \mathrm{P}$ ratios may be affected by various risk factors as follows.

$$
\begin{aligned}
& \frac{\Delta V_{R I V C}}{P}\left(\frac{\Delta V_{R I V I}}{P}, \frac{\Delta V_{A V E R}}{P}, \Delta T A R G E T, \triangle R E C O M\right)=\beta_{0}+\beta_{1} \text { lag } \triangle I N S T I T \\
& +\beta_{2} \text { InSIZE }+\beta_{3} B E T A+\beta_{4} I D R I S K+\beta_{5} O I V O L+\beta_{6} \operatorname{In} B / M+\beta_{7} \operatorname{InD} / M \\
& + \text { Year Dummies }+ \text { Industry Dummies }+\varepsilon
\end{aligned}
$$

where $\Delta V_{R I V C} / P$ are the change of equity value estimates, which is inferred from $R I V C$ model, scaled by stock price during the year; $\Delta V_{R I V I} / P$ are the change of equity value estimates, which is inferred from RIVI model, scaled by stock price during the year; $\triangle V_{A V E R} / P$ is the change of the average of $V_{R I V C} / P$ and $V_{R I V I} / P$ during the year; $\triangle T A R G E T$ is the change of SSAs' target price divided by the stock price during the year; $\triangle R E C O M$ is the change of SSAs' stock recommendation during the year; lagAINSTIT is the change in institutional ownership during the previous year; $\operatorname{lnSIZE}$ is the natural $\log$ of the market value of equity; BETA is the systematic risk estimated by regressing 30 prior monthly stock return and up to 60 prior monthly returns against the corresponding market index; IDRISK is the idiosyncratic risk, measured as the variance of residuals from the regressions of BETA estimation; OIVOL is the standard deviation of operating income during the past two to five years, scaled by average total asset; $\ln B / M$ is the natural $\log$ of ratio of book value of equity to market value of equity; $\ln D / M$ is the natural $\log$ of ratio of book value of debt to market value of equity; Year Dummies are year indicators; Industry Dummies are industry indicators based on the two-digit industry code.

\subsection{Sample Selection}

Our empirical analysis is based on a sample of Korean firms from 2001 to 2011, which excludes the observations from 2008. This is because only few SSAs revised their earnings forecasts and stock recommendations during the global financial crisis in 2008, that is, SSAs in Korea did not play their role as information intermediaries in 2008 (Song \& Byun, 2013). ${ }^{3}$ We extract accounting and stock return data from the Korea Information Service Value (KisValue) database, institutional ownership, analysts' earnings forecast, target prices and stock recommendations data from the Fn-Guide database. ${ }^{4}$ We also use the three-year government bond rate as a proxy for risk-free rate to calculate cost of equity capital from the Economic Statistics System of the Bank of Korea. We select firm-year observations that satisfy:

(1) financial statement data, which is required for computation of the main variables, industry identification codes, and stock return data are available from KisValue;

(2) stock price, analysts' information, institutional ownerships are available from Fn-Guide;

(3) non-financial firm;

(4) fiscal year-end is December;

(5) book value of equity is positive.

This process yields a final sample of 1,421 firm-year observations from KSE/KOSDAQ listing firms between 2001 and 2011. This final sample is used for the descriptive statistics in Table $1 .{ }^{5}$

\footnotetext{
${ }^{3}$ As a sensitivity test, we rerun our main empirical analyses after including the observations from 2008 . The main result remains constant.

${ }^{4}$ Because Fn-Guide provides analysts data from 2001 and institutional ownership data until 2011, our sample period is restricted to such a period.

${ }^{5}$ To mitigate the effect of outliers, all variables are winsorized at $5 \%$ and $95 \%$ of the pooled distributions.
} 


\section{EMPIRICAL RESULTS}

\subsection{Descriptive Statistics and Univariate Analysis}

Descriptive statistics of our sample are reported in Table 1. The mean values of $V_{R I V C} / P, V_{R I V I} / P, V_{A V E R} / P$ are 1.571 , 2.113 , and 1.854, respectively. These results are consistent with previous study (Cha \& Yoo, 2010). The mean value of TARGET is 1.209 , which indicates that SSAs evaluate the stock price as undervalued by $21 \%$ on average. The average of ROCOM (3.701) suggests that SSAs encourage investors to buy the stock on average. This is also consistent with prior studies (Kho \& Kim, 2007; Cha \& Yoo, 2010), which suggest that SSAs' stock recommendations are optimistically biased in Korean stock market. Although all of SSAs' mispricing indicators are optimistically biased on average, such an average bias has no effect on the interpretation of our empirical results. This is because our empirical specification is based on the association between the change of institutional ownership and relative magnitude of SSAs' mispricing indicators.

The descriptive statistics of control variables are as follows. The mean value (standard deviation) of SIZE, YIELD, LEVERAGE, VOLUME, and lagRET12 are 1,915 billion Korean Won (3,091 billion), 0.020 (0.016), 0.439 (0.171), 0.008 (0.006), and $0.413(0.645)$, respectively. The mean value (standard deviation) of the remaining control variables, which are frequently used as risk proxies, BETA, IDRISK, OIVOL, $B / M$, and $D / M$ are $0.982(0.354), 0.018(0.011)$, 0.028 (0.019), 1.251 (0.902), and 1.259 (1.335), respectively.

Table 1 presents the distributions of main variables used in this study. $\triangle I N S T I T$ is a change in institutional ownership for a year after the SSAs' information is disclosed at the beginning of year; $V_{R I V C} / P$ are the equity value estimates, which is inferred from $R I V C$ model, scaled by stock price, at the beginning of the year; $V_{R I V I} / P$ are the equity value estimates, which is inferred from RIVI model, scaled by stock price, at the beginning of the year. See the main text for the details of the implementation of each valuation model; $V_{A V E R} / P$ is the average of $V_{R I V C} / P$ and $V_{R I V I} / P$; TARGET is the SSAs' target price divided by the stock price at the beginning of year; RECOM is the SSAs' stock recommendation at the beginning of year $(1=$ Strong Sell, $2=$ Sell, $3=$ Hold, $4=$ Buy, and $5=$ Strong Buy $)$; SIZE is the market value of equity at the beginning of year (Billion KRW); BETA is the systematic risk estimated by regressing 30 prior monthly stock return and up to 60 prior monthly returns against the corresponding market index; IDRISK is the idiosyncratic risk, measured as the variance of residuals from the regressions of BETA estimation; OIVOL is the standard deviation of operating income during the past two to five years, scaled by average total asset; $B / M$ is the ratio of book value of equity to market value of equity; $D / M$ is the ratio of book value of debt to market value of equity; YIELD is the dividend per share divided by stock price at the beginning of year; LEVERAGE is total liability divided by total assets; VOLUME is the average of the ratio of daily trading volume divided by the number of shares outstanding; lagRET12 is the stock return of each firm during the previous year; Although we use the logarithmic values of $S I Z E, B / M$, and $D / M$ in subsequent main analyses, we present the distributions of the raw values of these variables for a descriptive purpose. 
Table 1. Descriptive Statistics

\begin{tabular}{|l|c|c|c|c|c|c|c|c|c|c}
\hline Variables & Mean & Std. dev & $\mathbf{5 \%}$ & $\mathbf{1 0 \%}$ & $\mathbf{2 5 \%}$ & Median & $\mathbf{7 5 \%}$ & $\mathbf{9 0 \%}$ & $\begin{array}{c}\mathbf{9 5 \%} \\
\text { observations }\end{array}$ \\
\hline$\triangle I N S T I T$ & 0.005 & 0.068 & -0.123 & -0.087 & -0.037 & 0.002 & 0.046 & 0.098 & 0.138 & 1,421 \\
\hline$V_{\text {RIVC }} P$ & 1.571 & 0.849 & 0.521 & 0.635 & 0.911 & 1.350 & 2.040 & 2.914 & 3.554 & 1,421 \\
\hline$V_{\text {RIVI }} P$ & 2.113 & 1.628 & 0.499 & 0.641 & 0.954 & 1.556 & 2.662 & 4.809 & 6.440 & 1,421 \\
\hline$V_{A V E R} / P$ & 1.854 & 1.202 & 0.527 & 0.652 & 0.966 & 1.470 & 2.331 & 3.862 & 4.865 & 1,421 \\
\hline TARGET & 1.209 & 0.195 & 0.907 & 0.965 & 1.063 & 1.185 & 1.322 & 1.490 & 1.617 & 1,421 \\
\hline RECOM & 3.701 & 0.320 & 3.000 & 3.170 & 3.500 & 3.800 & 4.000 & 4.000 & 4.000 & 1,421 \\
\hline SIZE & 1,915 & 3,091 & 45 & 67 & 161 & 477 & 2,010 & 6,232 & 11,580 & 1,421 \\
\hline BETA & 0.982 & 0.354 & 0.369 & 0.507 & 0.728 & 0.953 & 1.221 & 1.509 & 1.672 & 1,421 \\
\hline IDRISK & 0.018 & 0.011 & 0.005 & 0.007 & 0.010 & 0.015 & 0.023 & 0.036 & 0.046 & 1,421 \\
\hline OIVOL & 0.028 & 0.019 & 0.005 & 0.008 & 0.013 & 0.023 & 0.037 & 0.058 & 0.072 & 1,421 \\
\hline B/M & 1.251 & 0.902 & 0.270 & 0.366 & 0.572 & 0.964 & 1.637 & 2.765 & 3.521 & 1,421 \\
\hline D/M & 1.259 & 1.335 & 0.112 & 0.168 & 0.335 & 0.710 & 1.647 & 3.446 & 4.946 & 1,421 \\
\hline YIELD & 0.020 & 0.016 & 0.000 & 0.001 & 0.008 & 0.016 & 0.029 & 0.045 & 0.058 & 1,421 \\
\hline LEVERAGE & 0.439 & 0.171 & 0.147 & 0.186 & 0.303 & 0.451 & 0.575 & 0.669 & 0.718 & 1,421 \\
\hline VOLUME & 0.008 & 0.006 & 0.001 & 0.002 & 0.003 & 0.007 & 0.011 & 0.018 & 0.024 & 1,421 \\
\hline lagRET12 & 0.413 & 0.645 & -0.416 & -0.259 & -0.043 & 0.256 & 0.744 & 1.449 & 1.947 & 1,421 \\
\hline
\end{tabular}

Table 2 presents the Pearson correlation coefficients between key variables. The association between the change of institutional investors' ownership ( $\triangle I N S T I T)$ and the level of $\mathrm{V} / \mathrm{P}$ ratios $\left(V_{R I V C} / P, V_{R I V I} / P\right.$, and $\left.V_{A V E R} / P\right)$ and target price (TARGET) is significantly positive at the $1 \%$ significance level. This result indicates that institutional investors incorporate such SSAs' information more rapidly than individual investors. The correlations among analysts' information are consistent with previous research (Cha \& Yoo 2010). For example, there are significantly positive correlations among the $\mathrm{V} / \mathrm{P}$ ratios $\left(V_{R I V C} / P, V_{R I V I} / P\right.$, and $\left.V_{A V E R} / P\right)$, ranging from 0.786 to 0.971 . The associations between target price (TARGET) and V/P ratios are also significant and range from 0.093 to 0.270 . The correlation between target price (TARGET) and stock recommendation (RECOM) is also significantly positive (0.309). Lastly, unreported results indicate that there are significantly positive associations between V/P ratios and one-year-ahead stock returns, which range from 0.228 to 0.299 . This result indicates that V/P ratios incorporating SSAs' earnings forecasts can be considered as the indicator of stock market's mispricing based on SSAs' earnings forecasts. The significant correlations between the change of institutional investors' ownership ( $\triangle I N S T I T)$ and control variables and also between SSAs' mispricing indicators $\left(V_{R I V C} / P, V_{R I V I} / P, V_{A V E R} / P, T A R G E T, R E C O M\right)$ and control variables indicate that we need to examine the results of multivariate analyses, which are presented in next section.

Table 2 presents Pearson correlations between key variables for the pooled sample. Please see the note of Table 1 for the definitions of variables except followings. InSIZE is the natural $\log$ of the market value of equity. $\ln B / M$ is the natural $\log$ of ratio of book value of equity to market value of equity. $\ln D / M$ is the natural $\log$ of ratio of book value of debt to market value of equity. $* * *, * * *$ indicate, respectively, the significance level at the $1 \%, 5 \%$, and $10 \%$ level or better. 
Table 2. Pair-Wise Correlations Between Key Variables

\begin{tabular}{|c|c|c|c|c|c|c|c|}
\hline & $\triangle I N S T I T$ & $V_{R I V d} / P$ & $V_{R I V I} / P$ & $V_{A V E R} / P$ & TARGET & RECOM & $\operatorname{lnSIZE}$ \\
\hline$V_{R I V C} / P$ & $0.166^{* * *}$ & & & & & & \\
\hline$V_{R I V I} / P$ & $0.125^{* * *}$ & $0.786^{* * *}$ & & & & & \\
\hline$V_{A V E R} / P$ & $0.144^{* * *}$ & $0.900^{* * *}$ & $0.971^{* * *}$ & & & & \\
\hline TARGET & $0.074^{* * *}$ & $0.270^{* * *}$ & $0.093^{* * *}$ & $0.162^{* * *}$ & & & \\
\hline RECOM & -0.026 & -0.029 & $-0.122^{* * *}$ & $-0.094^{* * *}$ & $0.309^{* * *}$ & & \\
\hline $\ln S I Z E$ & $-0.092^{* * *}$ & $-0.397^{* * *}$ & $-0.327^{* * *}$ & $-0.371^{* * *}$ & $-0.206^{* * *}$ & $0.165^{* * *}$ & \\
\hline BETA & $-0.060^{* *}$ & $-0.390^{* * *}$ & $-0.394^{* * *}$ & $-0.412^{* * *}$ & $0.075^{* * *}$ & $0.113^{* * *}$ & $0.109^{* * *}$ \\
\hline IDRISK & $0.124^{* * *}$ & $0.116^{* * *}$ & 0.032 & $0.066^{* *}$ & $0.138^{* * *}$ & $-0.126^{* * *}$ & $-0.308^{* * *}$ \\
\hline OIVOL & $0.058^{* *}$ & $-0.046^{* *}$ & $-0.050^{*}$ & $-0.054^{* *}$ & $0.050^{*}$ & $0.094^{* * *}$ & $0.065^{* *}$ \\
\hline $\ln B / M$ & 0.030 & $0.407^{* * *}$ & $0.377^{* * *}$ & $0.406^{* * *}$ & $0.176^{* * *}$ & $-0.217^{* * *}$ & $-0.581^{* * *}$ \\
\hline $\ln D / M$ & 0.005 & $0.302^{* * *}$ & $0.245^{* * *}$ & $0.279^{* * *}$ & $0.176^{* * *}$ & $-0.176^{* * *}$ & $-0.323^{* * *}$ \\
\hline YIELD & $0.093^{* * *}$ & $0.303^{* * *}$ & $0.235^{* * *}$ & $0.274^{* * *}$ & $0.071^{* * *}$ & $-0.102^{* * *}$ & $-0.268^{* * *}$ \\
\hline LEVERAGE & -0.025 & 0.032 & -0.018 & 0.002 & $0.067^{* *}$ & $-0.051^{*}$ & $0.089^{* * *}$ \\
\hline VOLUME & $0.130^{* * *}$ & -0.006 & $-0.091^{* * *}$ & $-0.061^{* *}$ & $0.143^{* * *}$ & $-0.055^{* *}$ & $-0.170^{* * *}$ \\
\hline lagRET12 & -0.024 & $-0.153^{* * *}$ & $-0.090^{* * *}$ & $-0.120^{* * *}$ & $-0.197^{* * *}$ & $0.280^{* * *}$ & $0.097^{* * *}$ \\
\hline No. of observations & 1,421 & 1,421 & 1,421 & 1,421 & 1,421 & 1,421 & 1,421 \\
\hline
\end{tabular}

\begin{tabular}{|c|c|c|c|c|c|c|c|c|}
\hline & $B E T A$ & IDRISK & OIVOL & $\ln B / M$ & $\ln D / M$ & YIELD & LEVERAGE & VOLUME \\
\hline IDRISK & $0.272^{* * *}$ & & & & & & & \\
\hline OIVOL & $0.119^{* * *}$ & $0.124^{* * *}$ & & & & & & \\
\hline $\ln B / M$ & $-0.044^{*}$ & $0.144^{* * *}$ & $-0.270^{* * *}$ & & & & & \\
\hline $\ln D / M$ & $0.156^{* * *}$ & $0.272^{* * *}$ & $-0.298^{* * *}$ & $0.684^{* * *}$ & & & & \\
\hline YIELD & $-0.196^{* * *}$ & 0.032 & $-0.136^{* * *}$ & $0.412^{* * *}$ & $0.243^{* * *}$ & & & \\
\hline LEVERAGE & $0.265^{* * *}$ & $0.240^{* * *}$ & $-0.172^{* * *}$ & 0.036 & $0.730^{* * *}$ & $-0.053^{* *}$ & & \\
\hline VOLUME & $0.344^{* * *}$ & $0.405^{* * *}$ & $0.142^{* * *}$ & $0.045^{*}$ & $0.137^{* * *}$ & $0.074^{* * *}$ & $0.149^{* * *}$ & \\
\hline lagRET12 & $0.144^{* * *}$ & $0.086^{* * *}$ & $0.181^{* * *}$ & $-0.210^{* * *}$ & $-0.074^{* * *}$ & $-0.131^{* * *}$ & $0.091^{* * *}$ & $0.139^{* * *}$ \\
\hline No. of observations & 1,421 & 1,421 & 1,421 & 1,421 & 1,421 & 1,421 & 1,421 & 1,421 \\
\hline
\end{tabular}

\subsection{Multivariate Analysis}

Table 3 reports the results of multivariate regressions of the change of institutional ownership on SSAs' mispricing indicators which test our first hypothesis. Panel A of Table 3 shows that the change of institutional ownership is positively associated with each of all SSAs' mispricing indicators, $V_{R I V C} / P, V_{R I V I} / P, V_{A V E R} / P, T A R G E T$, and RECOM. The t-statistics range from 2.40 to 4.11 . Furthermore, we investigate which mispricing indicators of SSAs among V/P ratio, target price and stock recommendation is incrementally incorporated into the institutional investors' stock trading.

Table 3 presents the pooled sample regressions of the change in institutional ownership on the equity value estimates inferred from analysts' earnings forecasts scaled by stock prices (V/P ratio), target prices scaled by stock prices, and stock recommendations with control variables. See the notes of Table 1 and 2 for the definitions of variables. Adj. $\mathrm{R}^{2}$ is the adjusted $\mathrm{R}^{2}$ for the regressions. ${ }^{* *}, * *, *$ indicate, respectively, the $1 \%, 5 \%$, and $10 \%$ significance levels. The regression equations are as follows. 
Table 3. Regressions of the Change in Institutional Ownership on the SSAs' Mispricing Indicators

\begin{tabular}{|c|c|c|c|c|c|c|c|c|c|c|}
\hline $\begin{array}{l}\text { Panel A. Depender } \\
\Delta I N S T I T=\beta_{0}+\beta_{1} V_{R} \\
+\beta_{9} V O L U M E+\beta_{10} l\end{array}$ & $\begin{array}{l}\text { variable }= \\
C / P\left(V_{R I V I} / P\right. \\
R E T 12+Y\end{array}$ & $\begin{array}{l}\triangle I N S T I T \\
\left.V_{\text {AVER }} / P\right) \\
\text { ar Dumm }\end{array}$ & $\begin{array}{l}\text { TARGET } \\
+ \text { Industry }\end{array}$ & $\begin{array}{c}\beta_{3} \text { RECC } \\
\text { Dummies }\end{array}$ & $+\beta_{4} \ln S I Z E$ & $+\beta_{5}$ YIEL & $+\beta_{6} B E T A$ & $\beta_{7} \ln B / N$ & $\beta_{8} L E V E R$ & \\
\hline \multirow[b]{2}{*}{ Variables } & \multicolumn{2}{|c|}{ (1) } & \multicolumn{2}{|c|}{ (2) } & \multicolumn{2}{|c|}{ (3) } & \multicolumn{2}{|c|}{ (4) } & \multicolumn{2}{|c|}{ (5) } \\
\hline & Coef. & t stat. & Coef. & t stat. & Coef. & t stat. & Coef. & t stat. & Coef. & t stat. \\
\hline Intercept & -0.014 & -0.35 & 0.018 & 0.46 & 0.026 & 0.70 & 0.001 & 0.03 & -0.021 & -0.50 \\
\hline$V_{R I V C} / P$ & $0.012^{* * *}$ & 4.11 & & & & & & & & \\
\hline$V_{R I V I} / P$ & & & $0.004^{* * *}$ & 2.74 & & & & & & \\
\hline$V_{A V E R} / P$ & & & & & $0.002^{* *}$ & 2.40 & & & & \\
\hline TARGET & & & & & & & $0.024^{* *}$ & 2.40 & & \\
\hline RECOM & & & & & & & & & $0.018^{* * *}$ & 3.01 \\
\hline $\ln S I Z E$ & 0.000 & 0.05 & -0.000 & -0.53 & -0.000 & -0.60 & -0.000 & -0.48 & -0.001 & -0.93 \\
\hline YIELD & 0.061 & 0.49 & 0.106 & 0.86 & 0.117 & 0.95 & 0.106 & 0.86 & 0.085 & 0.69 \\
\hline BETA & 0.006 & 1.06 & 0.003 & 0.54 & -0.000 & -0.11 & -0.004 & -0.77 & -0.004 & -0.79 \\
\hline $\ln B / M$ & $-0.015^{* * *}$ & -4.18 & $-0.014^{* * *}$ & -3.98 & $-0.013^{* * *}$ & -3.66 & $-0.011^{* * *}$ & -3.29 & $-0.010^{* * *}$ & -3.09 \\
\hline LEVERAGE & -0.015 & -1.41 & -0.012 & -1.09 & -0.009 & -0.87 & -0.010 & -0.92 & -0.005 & -0.53 \\
\hline VOLUME & $0.683^{* *}$ & 2.17 & $0.730^{* *}$ & 2.31 & $0.733^{* *}$ & 2.32 & $0.638^{* *}$ & 2.01 & $0.766^{* *}$ & 2.42 \\
\hline lagRET12 & -0.002 & -0.83 & -0.002 & -0.67 & -0.002 & -0.70 & -0.001 & -0.31 & -0.004 & -1.30 \\
\hline Year Dummies & \multicolumn{2}{|c|}{ Included } & \multicolumn{2}{|c|}{ Included } & \multicolumn{2}{|c|}{ Included } & \multicolumn{2}{|c|}{ Included } & \multicolumn{2}{|c|}{ Included } \\
\hline Industry Dummies & \multicolumn{2}{|c|}{ Included } & \multicolumn{2}{|c|}{ Included } & \multicolumn{2}{|c|}{ Included } & \multicolumn{2}{|c|}{ Included } & \multicolumn{2}{|c|}{ Included } \\
\hline Adj. $R^{2}$ & \multicolumn{2}{|c|}{0.166} & \multicolumn{2}{|c|}{0.161} & \multicolumn{2}{|c|}{0.160} & \multicolumn{2}{|c|}{0.160} & \multicolumn{2}{|c|}{0.162} \\
\hline N. & \multicolumn{2}{|c|}{1,421} & \multicolumn{2}{|c|}{1,421} & \multicolumn{2}{|c|}{1,421} & \multicolumn{2}{|c|}{1,421} & \multicolumn{2}{|c|}{1,421} \\
\hline
\end{tabular}

Panel B of Table 3 presents that both V/P ratio and stock recommendation are significantly associated with the change of institutional ownership, while the significance of association between target price and the change of institutional ownership disappears when all mispricing indicators are considered. This result implies that SSAs' target price does not provide incremental information to institutional investors beyond SSAs' earnings forecasts and stock recommendation. ${ }^{6}$

\begin{tabular}{|c|c|c|c|c|c|c|}
\hline \multicolumn{7}{|c|}{ Panel B. Dependent variable $=\Delta I N S T I T$} \\
\hline \multirow[b]{2}{*}{ Variables } & \multicolumn{2}{|c|}{ (6) } & \multicolumn{2}{|c|}{ (7) } & \multicolumn{2}{|c|}{ (8) } \\
\hline & Coef. & t stat. & Coef. & t stat. & Coef. & t stat. \\
\hline Intercept & -0.052 & -1.18 & -0.050 & -1.11 & -0.047 & -1.06 \\
\hline$V_{R I V C} / P$ & $0.010^{* * *}$ & 3.14 & & & & \\
\hline$V_{R I V / P} / P$ & & & $0.003^{* *}$ & 2.30 & & \\
\hline$V_{A V E R} / P$ & & & & & $0.002^{* *}$ & 2.13 \\
\hline TARGET & 0.003 & 0.30 & 0.010 & 0.91 & 0.011 & 1.02 \\
\hline$R E C O M$ & $0.011^{*}$ & 1.68 & $0.014^{* *}$ & 2.16 & $0.015^{* *}$ & 2.26 \\
\hline $\ln S I Z E$ & -0.000 & -0.04 & -0.000 & -0.40 & -0.000 & -0.43 \\
\hline YIELD & 0.049 & 0.40 & 0.079 & 0.64 & 0.086 & 0.69 \\
\hline BETA & 0.004 & 0.65 & 0.001 & 0.19 & -0.002 & -0.36 \\
\hline $\ln B / M$ & $-0.014^{* * *}$ & -3.89 & $-0.013^{* * *}$ & -3.73 & $-0.012^{* * *}$ & -3.49 \\
\hline LEVERAGE & -0.013 & -1.20 & -0.010 & -0.97 & -0.008 & -0.79 \\
\hline VOLUME & $0.717^{* *}$ & 2.26 & $0.751^{* *}$ & 2.36 & 0.752 & 2.36 \\
\hline lagRET12 & -0.004 & -1.18 & -0.003 & -1.12 & -0.004 & -1.17 \\
\hline Year Dummies & \multicolumn{2}{|c|}{ Included } & \multicolumn{2}{|c|}{ Included } & \multicolumn{2}{|c|}{ Included } \\
\hline Industry Dummies & \multicolumn{2}{|c|}{ Included } & \multicolumn{2}{|c|}{ Included } & \multicolumn{2}{|c|}{ Included } \\
\hline Adj. $R^{2}$ & \multicolumn{2}{|c|}{0.168} & \multicolumn{2}{|c|}{0.166} & \multicolumn{2}{|c|}{0.165} \\
\hline $\mathrm{N}$. & \multicolumn{2}{|c|}{1,421} & \multicolumn{2}{|c|}{1,421} & \multicolumn{2}{|c|}{1,421} \\
\hline
\end{tabular}

\footnotetext{
${ }^{6}$ Jegadeesh and Kim (2006) and Bradshaw et al. (2013) consider the change of SSAs' target price or stock recommendation as the SSAs' mispricing indicator. Following these studies, we regress the change in institutional ownership on the change of SSAs' mispricing indicators $\left(\Delta V_{R I V C} / P, \Delta V_{R I V} / P\right.$, $\triangle V_{A V E R} / P, \triangle T A R G E T$, and $\left.\triangle R E C O M\right)$ as a robustness check. Untabulated results indicate that the change of institutional ownership is positively associated with the change of $\mathrm{V} / \mathrm{P}$ ratio and the change of stock recommendation, which is consistent with our main results.
} 
In sum, our main empirical results in Table 3 indicate that there is a positive association between the change of institutional ownership and SSAs' mispricing indicator, such as V/P ratio and stock recommendation. This result is consistent with our first hypothesis that institutional investors incorporate SSAs' indicators of stock market's mispricing more actively than individual investors taking a role to enhance the extent of stock market efficiency.

In previous analysis, we regress the change of institutional ownership during a year on the level of SSAs' mispricing indicator at the beginning of that year. Thus, there is less possibility that unknown common factors affect simultaneously both the change of institutional ownership and SSAs' mispricing indicator. However, we cannot fully rule out such a possibility. Thus, to strengthen the causal relationship between the change of institutional ownership and SSAs' mispricing indicators, we examine whether institutional investors' stock trading affects SSAs' mispricing indicators as an alternative hypothesis for the association between the change of institutional ownership and SSAs' mispricing indicators. More specifically, we regress the change of SSAs' mispricing indicators during a year on the previous year's change of institutional ownership. If we don't observe a significant association between those two variables, we can, at least partially, address such a potential causality issue.

Table 4 presents the results of empirical analysis to examine such an alternative hypothesis. As presented in Table 4, the association between the change of SSAs' mispricing indicators $\left(\triangle V_{R I V C} / P, \Delta V_{R I V I} / P, \Delta V_{A V E R} / P, \triangle T A R G E T\right.$, $\triangle R E C O M$ ) and the previous year's change of institutional ownership is not statistically significant. That is, we cannot find any evidence that SSAs' information is affected by institutional investors' trading behavior. Therefore, we suggest that our main results may support the causality relationship in which institutional investors incorporate SSAs' guidance on their stock trading, but not vice versa.

Table 4 presents the pooled sample regressions of the change of sell-side analysts' mispricing indicators, such as the equity value estimates inferred from analysts' earnings forecasts scaled by stock prices (V/P ratio), target prices scaled by stock prices, and stock recommendations, on the previous year's change in institutional ownership with control variables. See the notes of Table 1 and 2 for the definitions of variables, except lagAINSTIT which is the change in institutional ownership during the previous year. Adj. $\mathrm{R}^{2}$ is the adjusted $\mathrm{R}^{2}$ for the regressions. $* * * * *, *$ indicate, respectively, the $1 \%, 5 \%$, and $10 \%$ significance levels. The regression equations are as follows.

Table 4. Regressions of the Change of SSAs' Mispricing Indicators on the Change in Institutional Ownership

\begin{tabular}{|c|c|c|c|c|c|c|c|c|c|c|}
\hline \multicolumn{11}{|c|}{$\begin{array}{l}\Delta V_{R I V C} / P\left(\triangle V_{R I V I} / P, \Delta V_{A V E R} / P, \Delta T A R G E T, \triangle R E C O M\right)=\beta_{0}+\beta_{1} \operatorname{lag} \Delta I N S T I T+\beta_{2} \ln S I Z E+\beta_{3} B E T A+\beta_{4} I D R I S K+\beta_{5} O I V O L+\beta_{6} \ln B / M \\
+\beta_{7} \ln D / M+\text { Year Dummies }+ \text { Industry Dummies }+\varepsilon\end{array}$} \\
\hline \multirow[b]{2}{*}{ Variables } & \multicolumn{2}{|c|}{$\underset{\Delta V_{R I V C} / P}{(1)}$} & \multicolumn{2}{|c|}{$\underset{\Delta V_{R I V /} / P}{(2)}$} & \multicolumn{2}{|c|}{$\begin{array}{c}(3) \\
\Delta V_{A V E R} / P\end{array}$} & \multicolumn{2}{|c|}{$\begin{array}{c}(4) \\
\triangle T A R G E T\end{array}$} & \multicolumn{2}{|c|}{$\begin{array}{c}(5) \\
\triangle R E C O M\end{array}$} \\
\hline & Coef. & t stat. & Coef. & t stat. & Coef. & t stat. & Coef. & t stat. & Coef. & t stat. \\
\hline Intercept & $-1.729^{* * *}$ & -5.01 & -0.323 & -0.65 & $-4.885^{* * *}$ & -3.24 & $-6.113^{* * *}$ & -6.53 & 0.070 & 0.91 \\
\hline$V_{R I V C} / P$ & -0.250 & -1.16 & -0.269 & -0.86 & 1.367 & 1.32 & -0.197 & -0.33 & 0.052 & 0.99 \\
\hline$V_{R I V I} / P$ & $0.081^{* * *}$ & 6.85 & $0.051^{* * *}$ & 2.98 & $0.208^{* * *}$ & 3.99 & $0.218^{* * *}$ & 6.74 & -0.002 & -0.83 \\
\hline$V_{A V E R} / P$ & $-0.344^{* * *}$ & -6.68 & $-0.589^{* * *}$ & -7.93 & $-0.671^{* * *}$ & -2.91 & -0.195 & -1.39 & 0.000 & 0.05 \\
\hline TARGET & 2.154 & 1.18 & 1.373 & 0.52 & 11.952 & 1.40 & 5.094 & 1.03 & $0.722^{*}$ & 1.66 \\
\hline RECOM & $1.627^{*}$ & 1.87 & -0.152 & -0.12 & -4.235 & -1.06 & 0.358 & 0.15 & 0.201 & 0.99 \\
\hline $\ln S I Z E$ & $0.114^{* * *}$ & 3.87 & $0.088^{* *}$ & 2.07 & 0.130 & 0.98 & 0.122 & 1.52 & 0.002 & 0.42 \\
\hline$Y I E L D$ & 0.004 & 0.28 & 0.010 & 0.44 & 0.009 & 0.13 & 0.024 & 0.55 & 0.001 & 0.35 \\
\hline Year Dummies & \multicolumn{2}{|c|}{ Included } & \multicolumn{2}{|c|}{ Included } & \multicolumn{2}{|c|}{ Included } & \multicolumn{2}{|c|}{ Included } & \multicolumn{2}{|c|}{ Included } \\
\hline Industry Dummies & \multicolumn{2}{|c|}{ Included } & \multicolumn{2}{|c|}{ Included } & \multicolumn{2}{|c|}{ Included } & \multicolumn{2}{|c|}{ Included } & \multicolumn{2}{|c|}{ Included } \\
\hline Adj. $R^{2}$ & \multicolumn{2}{|c|}{0.264} & \multicolumn{2}{|c|}{0.430} & \multicolumn{2}{|c|}{0.077} & \multicolumn{2}{|c|}{0.180} & \multicolumn{2}{|c|}{0.074} \\
\hline N. & \multicolumn{2}{|c|}{1,365} & \multicolumn{2}{|c|}{1,365} & \multicolumn{2}{|c|}{1,365} & \multicolumn{2}{|c|}{1,365} & \multicolumn{2}{|c|}{1,365} \\
\hline
\end{tabular}

To test our second hypothesis, we divide the whole sample into two sub-samples on the basis of the accuracy of analysts' earnings forecasts. We measure the accuracy of analysts' earnings forecasts by their forecast errors, which are the absolute value of one-year-ahead analysts' earnings forecasts minus the actual earnings, scaled by stock price. Then, we identify two sub-samples with analysts' forecast errors which is less or more than the median of forecast errors in the whole sample (0.029). Then, we repeat our regression analysis in Table 3 separately for each of subsample. 
Panel A of Table 5 presents the regression results for the first sub-sample with analysts' earnings forecast errors less than the median. As reported in Panel A of Table 5, the coefficient of $V_{R I V C} / P, V_{R I V I} / P, V_{A V E R} / P$, and $R E C O M$ are significantly positive. This result implies that institutional investors incorporate SSAs' mispricing indicators, such as $\mathrm{V} / \mathrm{P}$ ratio and stock recommendation, more rapidly than individual investors when analysts provide more accurate earnings forecasts.

Table 5 presents the results of regressions of the change in institutional ownership on the equity value estimates inferred from analysts' earnings forecasts scaled by stock prices (V/P ratio), target prices scaled by stock prices, and stock recommendations with control variables for each sub-sample based on analysts' earnings forecasts errors. Panel A presents the results for the first sub-sample with analysts' earnings forecasts errors less than the median of the whole sample. Panel B report the results for the second sub-sample with analysts' earnings forecasts errors more than the median of the whole sample. See the notes of Table 1 and 2 for the definitions of variables. Adj. $\mathrm{R}^{2}$ is the adjusted $\mathrm{R}^{2}$ for the regressions. $* * *, * * *$ indicate, respectively, the $1 \%, 5 \%$, and $10 \%$ significance levels. The regression equations are as follows.

Panel B of Table 5 presents the regression results for the second sub-sample with analysts' earnings forecast errors more than the median. As reported in Panel B of Table 5, the coefficient of $V_{R I V C} / P, V_{R I V I} / P, V_{A V E R} / P$, and TARGET are not statistically significant, while only the coefficient of RECOM is weakly significant at the $10 \%$ level. This result suggests that institutional investors may not actively incorporate the mispricing indicators of analysts who have issued less accurate earnings forecasts.

Table 5. Regressions of the Change in Institutional Ownership on the SSAs' Mispricing Indicators for the Sub-Samples based on Analysts' Earnings Forecast Errors

Panel A. Dependent variable $=\triangle I N S T I T$

$\triangle I N S T I T=\beta_{0}+\beta_{1} V_{R I V C} / P\left(V_{R I V I} / P, V_{A V E R} / P\right)+\beta_{2}$ TARGET $+\beta_{3} R E C O M+\beta_{4} \ln S I Z E+\beta_{5} Y I E L D+\beta_{6} B E T A+\beta_{7} \ln B / M+\beta_{8} L E V E R A G E$

$+\beta_{9}$ VOLUME $+\beta_{10}$ lagRET12 + Year Dummies + Industry Dummies $+\varepsilon$

Analysts' Earnings Forecast Error < Median Value (0.029)

\begin{tabular}{|c|c|c|c|c|c|c|c|c|c|c|}
\hline \multirow[b]{2}{*}{ Variables } & \multicolumn{2}{|c|}{ (1) } & \multicolumn{2}{|c|}{ (2) } & \multicolumn{2}{|c|}{ (3) } & \multicolumn{2}{|c|}{ (4) } & \multicolumn{2}{|c|}{ (5) } \\
\hline & Coef. & t stat. & Coef. & t stat. & Coef. & t stat. & Coef. & t stat. & Coef. & t stat. \\
\hline Intercept & -0.008 & -0.12 & 0.046 & 0.74 & -0.010 & -0.82 & 0.083 & 1.24 & 0.026 & 0.39 \\
\hline$V_{R I V C} / P$ & $0.018^{* * *}$ & 3.67 & & & & & & & & \\
\hline$V_{R I V I} / P$ & & & $0.007^{* * *}$ & 2.90 & & & & & & \\
\hline$V_{A V E R} / P$ & & & & & $0.003^{*}$ & 1.78 & & & & \\
\hline TARGET & & & & & & & 0.008 & 0.50 & & \\
\hline RECOM & & & & & & & & & $0.021^{* *}$ & 2.27 \\
\hline $\operatorname{lnSIZE}$ & -0.001 & -0.72 & -0.003 & -1.49 & -0.000 & -0.42 & $-0.004^{*}$ & -1.87 & $-0.004^{* *}$ & -2.12 \\
\hline YIELD & 0.248 & 1.14 & 0.340 & 1.55 & 0.315 & 1.63 & 0.268 & 1.21 & 0.231 & 1.05 \\
\hline BETA & 0.011 & 1.15 & 0.007 & 0.80 & -0.002 & -0.26 & -0.003 & -0.42 & -0.004 & -0.53 \\
\hline $\ln B / M$ & $-0.013^{* *}$ & -2.32 & $-0.014^{* *}$ & -2.39 & -0.006 & -1.29 & -0.008 & -1.50 & -0.007 & -1.22 \\
\hline LEVERAGE & -0.024 & -1.30 & -0.021 & -1.13 & -0.013 & -0.87 & -0.015 & -0.83 & -0.015 & -0.82 \\
\hline VOLUME & $1.221^{* *}$ & 2.34 & $1.238^{* *}$ & 2.36 & $1.244^{* * *}$ & 2.62 & $1.192^{* *}$ & 2.25 & $1.272^{* *}$ & 2.42 \\
\hline lagRET12 & -0.001 & -0.26 & -0.000 & -0.03 & 0.000 & 0.06 & 0.000 & 0.08 & -0.002 & -0.51 \\
\hline Year Dummies & \multicolumn{2}{|c|}{ Included } & \multicolumn{2}{|c|}{ Included } & \multicolumn{2}{|c|}{ Included } & \multicolumn{2}{|c|}{ Included } & \multicolumn{2}{|c|}{ Included } \\
\hline Industry Dummies & \multicolumn{2}{|c|}{ Included } & \multicolumn{2}{|c|}{ Included } & \multicolumn{2}{|c|}{ Included } & \multicolumn{2}{|c|}{ Included } & \multicolumn{2}{|c|}{ Included } \\
\hline Adj. $R^{2}$ & \multicolumn{2}{|c|}{0.213} & \multicolumn{2}{|c|}{0.207} & \multicolumn{2}{|c|}{0.173} & \multicolumn{2}{|c|}{0.197} & \multicolumn{2}{|c|}{0.203} \\
\hline N. & \multicolumn{2}{|c|}{710} & \multicolumn{2}{|c|}{710} & \multicolumn{2}{|c|}{710} & \multicolumn{2}{|c|}{710} & \multicolumn{2}{|c|}{710} \\
\hline
\end{tabular}

(Table 5, Pane B continued on next page) 
(Table 5 continued)

\begin{tabular}{|c|c|c|c|c|c|c|c|c|c|c|}
\hline \multicolumn{11}{|c|}{$\begin{array}{l}\text { Panel B. Dependent variable }=\triangle I N S T I T \\
\text { Analysts' Earnings Forecast Error }<\text { Median Value } \mathbf{( 0 . 0 2 9 )}\end{array}$} \\
\hline \multirow[b]{2}{*}{ Variables } & \multicolumn{2}{|c|}{ (1) } & \multicolumn{2}{|c|}{ (2) } & \multicolumn{2}{|c|}{ (3) } & \multicolumn{2}{|c|}{ (4) } & \multicolumn{2}{|c|}{ (5) } \\
\hline & Coef. & t stat. & Coef. & t stat. & Coef. & t stat. & Coef. & t stat. & Coef. & t stat. \\
\hline Intercept & -0.031 & -0.46 & -0.013 & -0.20 & -0.018 & -0.28 & -0.048 & -0.68 & -0.061 & -0.84 \\
\hline$V_{R I V C} / P$ & 0.005 & 1.30 & & & & & & & & \\
\hline$V_{R I V I} / P$ & & & 0.001 & 0.62 & & & & & & \\
\hline$V_{A V E R} / P$ & & & & & 0.002 & 1.25 & & & & \\
\hline TARGET & & & & & & & 0.021 & 1.53 & & \\
\hline$R E C O M$ & & & & & & & & & $0.015^{*}$ & 1.73 \\
\hline $\ln S I Z E$ & 0.000 & 0.12 & -0.000 & -0.06 & -0.000 & -0.01 & 0.000 & 0.08 & -0.000 & -0.19 \\
\hline YIELD & -0.065 & -0.38 & -0.051 & -0.29 & -0.050 & -0.29 & -0.045 & -0.26 & -0.074 & -0.43 \\
\hline BETA & 0.003 & 0.32 & 0.000 & 0.08 & 0.001 & 0.12 & -0.002 & -0.22 & -0.001 & -0.15 \\
\hline $\ln B / M$ & $-0.023^{* * *}$ & -4.04 & $-0.023^{* * *}$ & -3.96 & $-0.023^{* * *}$ & -4.01 & $-0.022^{* * *}$ & -3.87 & $-0.021^{* * *}$ & -3.76 \\
\hline LEVERAGE & -0.004 & -0.23 & -0.003 & -0.16 & -0.003 & -0.17 & -0.003 & -0.18 & 0.001 & 0.06 \\
\hline VOLUME & 0.668 & 1.46 & 0.692 & 1.52 & 0.690 & 1.51 & 0.651 & 1.43 & $0.756^{*}$ & 1.65 \\
\hline lagRET12 & $-0.008^{*}$ & -1.70 & $-0.008^{*}$ & -1.70 & $-0.008^{*}$ & -1.72 & -0.007 & -1.49 & $-0.010^{* *}$ & -2.07 \\
\hline Year Dummies & \multicolumn{2}{|c|}{ Included } & \multicolumn{2}{|c|}{ Included } & \multicolumn{2}{|c|}{ Included } & \multicolumn{2}{|c|}{ Included } & \multicolumn{2}{|c|}{ Included } \\
\hline Industry Dummies & \multicolumn{2}{|c|}{ Included } & \multicolumn{2}{|c|}{ Included } & \multicolumn{2}{|c|}{ Included } & \multicolumn{2}{|c|}{ Included } & \multicolumn{2}{|c|}{ Included } \\
\hline Adj. $R^{2}$ & \multicolumn{2}{|c|}{0.217} & \multicolumn{2}{|c|}{0.216} & \multicolumn{2}{|c|}{0.217} & \multicolumn{2}{|c|}{0.218} & \multicolumn{2}{|c|}{0.219} \\
\hline N. & \multicolumn{2}{|c|}{711} & \multicolumn{2}{|c|}{711} & \multicolumn{2}{|c|}{711} & \multicolumn{2}{|c|}{711} & \multicolumn{2}{|c|}{711} \\
\hline
\end{tabular}

Taken together, the results in Table 5 indicate that the change of institutional ownership is significantly associated with SSAs' mispricing indicators only when analysts' earnings forecasts are more accurate, which is consistent with our second hypothesis. These results imply that institutional investors selectively incorporate more accurate SSAs' information into their stock trading. Thus, we can suggest that institutional investors may act as a more sophisticated mechanism to enhance stock market efficiency by distinguishing the quality of SSAs' information.

\section{CONCLUSION}

This study examines how institutional investors interact with sell-side analysts (hereafter, SSAs) in Korean stock market. We investigate the role of institutional investors as more sophisticated investors who incorporates sell-side analysts' earnings forecasts, target prices and stock recommendation more actively than individual investors do. Furthermore, we examine whether institutional investors can differentiate the quality of sell-side analysts' indicators of stock market's mispricing.

By using a sample of Korean firms during 2001-2011, we find that the change of institutional ownership has a significantly positive association with the level of equity value estimates based on SSAs' earnings forecasts relative to stock prices and their stock recommendation. Furthermore, we find that only when SSAs' earnings forecasts are more accurate, institutional investors incorporate SSA's information into their stock trading. Thus, we conclude that institutional investors in Korean stock market may contribute to the enhancement of stock market efficiency by incorporating SSAs' mispricing indicators more actively than individual investors.

This study makes several contributions to the literature as follows. First, this study provides a piece of evidence that institutional investors act as a more sophisticated mechanism in incorporating SSAs' mispricing indicators more rapidly than individual investors do. Second, this study suggests that institutional investors can selectively incorporate more accurate SSAs' information. This evidence adds to the prior literature which examines institutional investors' sophistication in stock market. Overall, this study contributes to the enhancement of our knowledge about the unobserved interaction among more sophisticated stock market participants who are considered to take an active role on the enhancement of stock market efficiency. 


\section{ACKNOWLEDGEMENT}

This work was supported by the Ministry of Education of the Republic of Korea and the National Research Foundation of Korea (NRF-2015S1A5A2A01012332).

\section{AUTHOR BIOGRAPHIES}

Grace II Joo Kang is a Lecturer at Singapore University of Social Sciences in Singapore (1st Author).

Yong Keun Yoo is a Professor at Korea University in Korea (Corresponding Author).

Seung Min Cha is an Associate Professor at Kyonggi University in Korea (Co-Author).

\section{REFERENCES}

Ali, A., Hwang, L., \& Trombley, M. (2003). Residual income-based valuation predicts future stock returns: Evidence on mispricing vs risk explanations. The Accounting Review, 78(2), 377-396.

Amihud, Y., \& Mendelson, H. (1986). Asset pricing and the bid ask spread. Journal of Financial Economics, 17, $223-249$.

Asquith, P., Mikhail, M., \& Au, A. (2005). Information content of equity analyst reports. Journal of Financial Economics, 75 , 245-282.

Bae, K., \& Park, B. (2007). A study on the relation of accounting information and institutional investors with outside directors. Korean Accounting Study, 12(3), 81-109.

Barber, B., Lehavy, R., McNichols, M., \& Truman, B. (2001). Can investors profit from the prophets? Security analyst recommendations and stock returns. Journal of Finance, 56, 531-563.

Barber, B., \& Odean, T. (2008). All that glitters: The effect of attention and news on the buying behavior of individual and institutional investors. Review of Financial Studies, 21, 785-818.

Bathala, C., Moon K., \& Rao, R. (1994). Managerial ownership, debt policy, and the impact of institutional holdings: An agency perspective. Financial Management, 23(3), 38-50.

Bianchini, R., Bonini, S., Salvi, A., \& Zanitti, L. (2008). Portfolio returns and target prices. Working paper.

Bradshaw, M. (2004). How do analysts use their earnings forecasts in generating stock recommendations? The Accounting Review, 79, 25-50.

Bradshaw, M., Brown, L., \& Huang, K. (2013). Do sell-side analysts exhibit differential target price forecasting ability? Review of Accounting Studies, 18, 930-955.

Brav, A., \& Lehavy, R. (2003). An empirical analysis of analysts' target prices: Short-term informativeness and long-term dynamics. Journal of Finance, 58, 1933-1968.

Brown, L., Griffin, P., Hagerman, R., \& Zmijewski, M. (1987). Security analyst superiority relative to univariate timeseries models in forecasting quarterly earnings. Journal of Accounting and Economics, 9, 61-87.

Busse, J., Green, T., \& Jegadeesh, N. (2012). Buy-side trades and sell-side recommendations: Interactions and information content. Journal of Financial Markets, 15, 207-232.

Cha, S., \& Yoo, Y. (2010). Relationships among analysts' earnings forecasts, target prices, and stock recommendations, and their abilities to predict future stock returns. Korean Management Review, 39(1), 29-54.

Chen, H., Jegadeesh, N., \& Wermers, R. (2000). The value of active mutual fund management: An examination of the stockholdings and trades of fund managers. Journal of Financial and Quantitative Analysis, 35, 343-368.

Chen, X., \& Cheng, Q. (2006). Institutional holdings and analysts' stock recommendations. Journal of Accounting, Auditing \& Finance, 399-440.

Cheng, Y., Liu, M., \& Qian, J. (2006). Buy-side analysts, sell-side analysts, and investment decisions of money managers. Journal of Financial \& Quantitative Analysis, 41(1), 51-84.

Easton, P. (2004). PE ratios, PEG ratios, and estimating the implied expected rate of return on equity capital. The Accounting Review, 79, 73-95.

Elgers, P., Lo, M., \& Pfeiffer, R. (2001). Delayed security price adjustments to financial analysts' forecasts of annual earnings. The Accounting Review, 76(4), 613-632.

Frankel, R., \& Lee, C. (1998). Accounting Valuation, Market Expectation, and cross-sectional Stock Returns. Journal of Accounting and Economics, 25, 283-319.

Gleason, C., \& Lee, C. (2003). Analyst forecast revisions and market price discovery. The Accounting Review, 78(1), $193-225$.

Gode, D., \& Mohanram, P. (2003). Inferring the Cost of Capital Using the Ohlson Juettner Model. Review of Accounting Studies $8,399-431$.

Gompers, P., \& Metrick, A. (2001). Institutional investors and equity prices. Quarterly Journal of Economics, 116, $229-259$.

Grinblatt, M., Titman, S., \& Wermers, R. (1995). Momentum investment strategies, portfolio performance, and herding: A study 
of mutual fund behavior. American Economic Review, 85, 1088-1105.

Grinblatt, M., \& Keloharju, M. (2000). The investment behavior and performance of various investor-types: A study of finland's unique data set. Journal of Financial Economics, 55, 43-67.

Groysberg, B., Healy, P., \& Serafeim, G. (2013). The stock selection and performance of buy-side analysts. Management Science, 59(5), 1062-1075.

Irvine, P. (2004). analysts' forecasts and brokerage-firm trading. The Accounting Review, 79, 125-149.

Jegadeesh, N., Kim, J., Krische, S., \& Lee, C. (2004). Analyzing the analysts: When do recommendations add value? The Journal of Finance, 59, 1083-1124.

Jegadeesh, N., \& Kim., J. (2006). Value of analyst recommendations: International evidence. Financial Markets, 9(3), 274-309.

Jiambalvo, J., Rajgopal, S., \& Venkatachalam, M. (2002). Institutional ownership and the extent to which stock prices reflect future earnings. Contemporary Accounting Research, 19(1), 17-45.

Jorgensen, B., Lee, Y., \& Yoo, Y. (2011). The valuation accuracy of equity value estimates inferred from conventional empirical implementations of the Abnormal Earnings Growth Model: US evidence. Journal of Business Finance and Accounting, $38,446-471$.

Kang, J., \& Stultz, R. (1997). Why is there a home bias? An analysis of foreign equity ownership in Japan. Ohio State University Working paper.

Kim, D., \& Cheon, Y. (2004). Foreign investors vs. domestic investors, who are better informed investors? Asia-Pacific Journal of Financial Studies, 33(2), 1-44.

Kim, D., \& Eum, S. (2006). The impact of analysts' revisions in their stock recommendation and target prices on stock prices. Asia-Pacific Journal of Financial Studies, 35(2), 75-108.

Kho, B., \& Kim, J. (2007). Earnings forecast accuracy and recommendation profitability of the analysts in Korea. Asia-Pacific Journal of Financial Studies, 36(6), 1009-1047.

Lee, C., Myers, J., \& Swaminathan, B. (1999). What is the intrinsic value of the Dow? Journal of Finance, 54, $1693-1741$.

Lee, C. (2001). Market efficiency and accounting research: A discussion of 'capital market research in accounting' by S.P. Kothari. Journal of Accounting and Economics, 31, 233-253.

Liu, J., Nissim, D., \& Thomas, J. (2002). Equity valuation using multiples. Journal of Accounting Research, 40, $135-172$.

Loh, R., \& Mian, G. (2006). Do accurate earnings forecasts facilitate superior investment recommendations? Journal of Financial Economics, 80, 455-483.

Malmendier, U., \& Shanthikumar, D. (2014). Do security analysts speak in two tongues? The Review of Financial Studies, 27(5), 1287-1322.

Nofsinger, J., \& Sias, R. (1999). Herding and feedback trading by institutional and individual investors. The Journal of Finance, 54, 2263-2295.

Odean, T. (1999). Do investors trade too much? American Economic Review, 89, 1279-1298.

Ohlson, J. (1995). Earnings, book values, and dividends in equity valuation. Contemporary Accounting Research, 11, $661-687$.

Sias, R., Starks, L., \& Titman, S. (2001). The price impact of institutional trading. Working paper. University of Texas and Washington State University.

Song, M., \& Byun, S. (2013). 2008 financial crisis and analyst forecasts. Korean Management Review, 42(5), $1187-1218$.

Stickel, S. (1991). Common stock returns surrounding earnings forecast revisions: More puzzling evidence. The Accounting Review, 66, 402-416.

Wermers, R. (1999). Mutual fund herding and the impact on stock prices. Journal of Finance, 54, 581-622.

Womack, K. (1996). Do brokerage analysts' recommendations have investment value? Journal of Finance, 51, $137-167$.

Yan, X., \& Z. Zhang. (2009). Institutional investors and equity returns: Are short-term investors better informed? Review of Financial Studies, 22, 893-924. 